\title{
Impact of biofilms in simulated drinking water and urban heat supply systems
}

\section{F.A. Lopes}

Laboratoire de Génie des Procédés et Matériaux, Laboratory of Chemical and Material Engineering, Ecole Centrale Paris, Grande Voie des Vignes, 92295 Châtenay-Malabry Cedex, France

Fax: +33141131163

E-mail: filipa.lopes@ecp.fr

\section{P. Morin}

BRAIBANT MORIN Expertises,

75 Avenue Parmentier, 75544 Paris Cedex 11, France

Fax: +33177759037

E-mail: p.morin@BMEX.fr

\section{R. Oliveira}

Department of Biological Engineering, University of Minho,

Campus de Gualtar, 4710-057 Braga, Portugal

Fax: +351253678986

E-mail: roliveira@deb.uminho.pt

\section{L.F. Melo*}

Faculty of Engineering,

Department of Chemical Engineering, University of Porto, P-4200465, Porto, Portugal

Fax: +351225081449

E-mail:1melo@fe.up.pt

${ }^{*}$ Corresponding author

\begin{abstract}
Biofouling and biocorrosion were studied in drinking water and heating water systems by forming biofilms on steel and on polymethylmetacrylate. In the drinking water system, biofilm development was more significant on corroded surfaces, suggesting that in these conditions they were largely protected from disinfection, probably because of sheltering and chlorine demand by corrosion products. In the urban heat supply system, results suggest a higher biofilm activity at lower $\mathrm{pH}$. Sulphate-reducing bacteria were detected in the urban heating biofilms, but little corrosion was observed on steel coupons. Results indicate that surface and bulk medium properties, as well as bacterial diversity are determinant parameters when studying biofouling and biocorrosion.
\end{abstract}


Keywords: biofilms; sulphate reducing bacteria; drinking water and urban heat supply systems; steel; PMMA; FISH.

Reference to this paper should be made as follows: Lopes, F.A., Morin, P., Oliveira, R. and Melo, L.F. (2009) 'Impact of biofilms in simulated drinking water and urban heat supply systems', Int. J. Environmental Engineering, Vol. 1, No. 3, pp.276-294.

Biographical notes: Filipa A. Lopes is an Assistant Professor at the Ecole Centrale Paris in Chatenay-Malabry, France. Her research interests include the Science and Engineering of biofilms (wastewater treatment, biofouling in industry, biocorrosion, sulphate-reducing bacteria), Biogeochemistry (anaerobic methane oxidation, reactive transport modelling) and Biotechnology of Microalgae.

Pierre Morin has recently started his own expertise company. He is an expert on water microbiology and chemistry. His previous research activities focused on biofilms in drinking water distribution systems.

Rosario Oliveira is a full Professor at the Department of Biological Engineering in Portugal and she is the Head of the Biofilm research group at the same university. Her research has been conducted in two different areas: Science and Engineering of biofilms (wastewater treatment and the control of undesired biofilms in indwelling medical devices, as well as in food contacting surfaces) and Solid Waste Treatment - focusing on the biological processes of treatment (composting and anaerobic digestion).

Luis F. Melo is a full Professor at the Faculty of Engineering at the University of Porto, Portugal, where he is the Head of the Research Center LEPAE (Laboratory for Process, Environmental and Energy Engineering) and a member of the scientific committee of the Bioengineering Programme at the Faculty of Engineering at the University of Porto. His research interests are in the field of biofilms, with applications to wastewater treatment, drinking water quality and biofouling in industry.

\section{Introduction}

Water used in domestic engineered systems is taken from natural sources (rivers, underground, etc.) containing various organic macro-molecules. These substances adsorb onto the pipe surfaces and act also as nutrients for the living cells, thereby supporting the biofilm growth process.

Biofilms are communities of micro-organisms (mostly, bacteria) attached to surfaces and embedded in a hydrated polymeric matrix excreted by the microbial cells. Biofilms develop through two parallel competitive processes: the 'growth' that includes cell attachment and biomass formation, and the 'detachment' by which micro-organisms and polymeric biomass are released from the biological layer (Melo, 2003).

Microbial films are beneficial when they are used in bioreactors for water and wastewater treatment, or for the production of specific chemicals (citric acid, biopolymers for the food industry, etc.). On the other hand, they are detrimental in many engineering systems, such as drinking water distribution networks and cooling water units, where they may affect the biostability of potable water 
(dissemination of pathogens), stimulate the corrosion of pipe walls and cause higher energy consumption in industrial plants (the growth of biofilm layers on tubes leads to higher pressure drop and lower heat transfer efficiency) (Bott, 1995).

The biofilms are formed by bacteria released from the drinking water treatment plant and from the erosion and sloughing of biofilms developing in other locations of the distribution network (Dunkelberger and Carey, 1991; Block et al., 1993; Laurent et al., 1993). The temperatures in these systems are usually quite suitable for microbial growth (from $15^{\circ} \mathrm{C}$ to $50^{\circ} \mathrm{C}$ ) and the flow conditions stimulate bacterial attachment to surfaces. The pressure exerted by the harsh conditions of the medium (disinfection applied at the treatment plant and in the distribution system, oligotrophic medium) is suitable for particularly resistant bacteria (Morin et al., 1999).

Biofilm control is, therefore, an important issue for the proper management of these engineered systems. The use of appropriate liquid velocities, temperatures and surface conditions can reduce biofouling effects, but is often not enough, and mechanical and chemical methods will have to be considered to mitigate biofouling effects (see detailed analysis in Bott, 1995; Videla, 2002). The most common method of minimising biofilm development is to apply disinfectants to kill or inactivate the micro-organisms, with chlorine as the most preferred biocide.

From an electrochemical point of view, corrosion is a chemical reaction involving the transfer of electrons from a zero valent metal to an external electron acceptor, causing the release of the metal ions into the surrounding medium and the deterioration of the metal. Corrosion products that are formed through these processes may adhere to the surface, forming a protective layer that provides a diffusion barrier to the reactants and decreases metal dissolution. The stability of such corrosion product layers depends on their chemistry and morphology and determines the overall susceptibility of the metal to corrosion (Beech and Sunner, 2004; Videla and Herrera, 2005).

Corrosion can be influenced by the presence of micro-organisms on the surface (Hamilton, 1995). The basic conditions leading to Microbial Influenced Corrosion (MIC) are present in water systems: bacteria and metallic surfaces become close together as biofilms attach to the pipe walls. Biofilms modify electrochemical processes, notably through their spatial heterogeneity. Differential concentration cells of dissolved oxygen can form between the biofilm and the substratum surface (Little et al., 1990; Patel and Bott, 1991; Xu et al., 1998). Biocorrosion is also a result of interactions, often synergistic, between metallic surface, abiotic corrosion products, and bacterial cells and their metabolites. The latter include organic and inorganic acids, such as hydrogen sulphide. Sulphate reducing bacteria are an environmentally important group of micro-organisms that utilise oxidised sulphur compounds as electron acceptors for the dissimilation of organic compounds and produce sulphide (Gibson, 1990). These bacteria are commonly associated with corrosion failures of mild steel and stainless steel surfaces (Hamilton, 1999; Geesey et al., 2000; Videla and Herrera, 2005; Lopes et al., 2006).

Corrosion on water pipes in drinking water systems is a costly phenomenon due to the replacement of damaged pipes and to the anti-corrosion treatments involved, and also in terms of the bad image given to the consumers when they are confronted with brown water.

Heated water networks are another example of engineering systems that suffer from corrosion. The presence of slime and sulphide has been reported in these systems, indicating that microbiologically induced corrosion phenomena may occur in these 
extreme environments and that sulphate reducers possibly contribute to corrosion failures (Goeres et al., 1998; Kjellerup et al., 2006).

Despite considerable research efforts into understanding biocorrosion, general issues, such as the importance of microbial ecology in MIC, must be addressed. It is important to identify, quantify and locate bacteria that are commonly associated with corrosion in order to control biofilm-related problems and to implement more efficient MIC prevention and protection measures.

Studies have been performed in order to determine the microbial diversity of biofilm communities in numerous environments like activated sludge and oligotrophic environments such as drinking water systems (Kalmbach et al., 1997), but the microbial ecology of biofilms developed in urban heat supply systems has not been broadly investigated and the impact of the attached bacteria in this environment is poorly understood.

The aim of this work was to study two engineered systems suffering from biofouling, a drinking water and an urban heat supply system, discussing some of the factors that affect biofilm formation and activity, as well as biofilm-corrosion relationships. Specifically, in the drinking water system case, a laboratory scale biofilm reactor was used to study the crossed influences established between biofilm and corrosion, and between these two components and a strong and widely used oxidant, chlorine. In the urban heat supply system, annular reactors were used as model systems and fluorescence in-situ hybridisation (FISH) was used to identify the dominant bacterial groups in biofilms formed on different materials (steel and polymeric surfaces) at two $\mathrm{pH}$ levels.

\section{Material and methods}

\subsection{Case 1: drinking water system}

\subsubsection{Laboratory system}

In order to grow biofilms in conditions relevant to drinking water distribution systems, we designed a bench-scale system that was plugged to the tap water. Parameters such as hydrodynamics, nutrient load, presence/absence of disinfectant and temperature were controlled. The laboratory system (Figure 1), which is partially described elsewhere (Morin et al., 1996), allows for the distribution of drinking water without chlorine residues and with a minimum concentration of utilisable organic carbon and other nutrients. The reactor used to grow biofilms was composed of two flow cells with semi-circular cross section which were connected in series in a recirculation loop. The total internal surface area of the reactor was $260 \mathrm{~cm}^{2}$. The water velocity in the flow cells was $0.35 \mathrm{~m} \mathrm{~s}^{-1}$ and the flow was turbulent (Reynolds number $\sim 5000$ ). The shear stress was $3 \mathrm{~N} . \mathrm{m}^{-2}$. The reactor behaved as a perfectly mixed continuously fed reactor with a residence time of $2 \mathrm{~h}$ (Pereira et al., 2002). Ten removable coupons placed along the flow cells were used to study biofilms on diverse materials without emptying the reactor. The temperature was maintained at $23^{\circ} \mathrm{C}$. The inlet reactor water was supplemented with an organic carbon solution (final concentration $0.5 \mathrm{mg} \mathrm{C} \mathrm{L}^{-1}$ ) and a nitrate buffer solution (final concentration $0.1 \mathrm{mg} \mathrm{N} \mathrm{L}^{-1}$ and $0.01 \mathrm{mg} \mathrm{P} \mathrm{L}^{-1}$ ). 
Figure 1 Laboratory set-up to study biofilms in drinking water systems

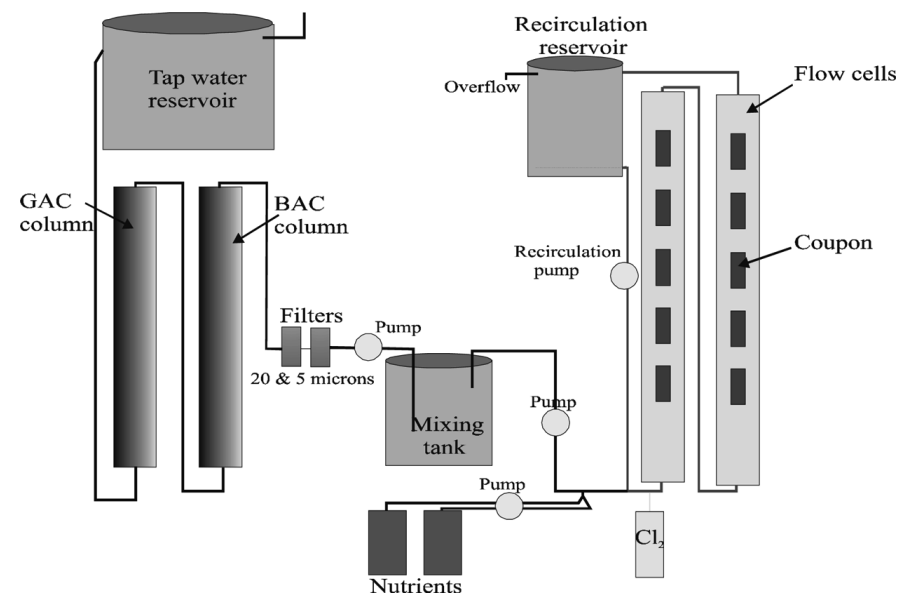

\subsubsection{Experimental strategy}

Each replicate experiment was conducted using two reactors in series, one containing mild steel coupons ('corroded' reactor) and the other one with non-corroding polymethylmetacrylate (control reactor). These coupons presented a surface area of $1.50 \mathrm{~cm}^{2}$. The biofilms reached a pseudo-steady state after a maximum of six days of run as measured by Heterotrophic Plate Count (HPC) and total bacteria concentration per surface area (data not shown). After at least seven days, two samples of the biofilm at steady state were generally taken. Chlorination at the reactor inlets started immediately after the second sample and lasted $48 \mathrm{~h}$. A third sample was removed after $12 \mathrm{~h}$; then, daily samples followed.

\subsubsection{Biofilm sampling and analyses}

Biofilms developed on the flow cell coupons were scraped in a sterile buffer solution, after rinsing with buffer, using sterile cell scrapers, and the suspension was homogenised for one minute at $27000 \mathrm{rpm}$. In order to avoid interference from the corrosion products when using 4'6-diamino-2-phenylindole (DAPI), the biofilm scraped and resuspended from mild steel coupons was centrifuged for $30 \mathrm{~min}$ at $500 \mathrm{rpm}$ and the supernatant recovered. Aliquots of the suspension (supernatant) were then utilised for the enumeration of cultivable and total bacteria. HPC bacteria were obtained by the spread plate method on R2A medium in triplicate and counted as Colony Forming Units (CFU) after 7 days of incubation at $23^{\circ} \mathrm{C}$. Cultivable bacteria were Gram-stained and tested for oxidase and catalase activities before biochemical identification of Gram negative bacteria with API $20 \mathrm{NE}$ tests. Total bacteria were estimated by DAPI staining $\left(0.1 \mathrm{gL}^{-1}\right)$ and direct epifluorescence microscopic enumeration. The size of the bacteria was measured from microscope photographs after DAPI staining. Over 600 bacteria were measured from eight biofilm samples per reactor (four replicate experiments). 


\subsubsection{Total iron bulk concentration measurement}

The total iron concentration in the bulk water effluent of the reactors was measured by spectrophotometry at $510 \mathrm{~nm}$ using the phenantroline method (Clesceri, 1989).

\subsubsection{Disinfectant and chlorine demand}

A concentrated chlorine solution was prepared from commercial sodium hypochlorite diluted with distilled water in a chlorine demand-free brown glass bottle. The chlorine solution was then pumped into the reactors with a peristaltic pump. Free chlorine concentration was measured using a DPD chlorine colorimetric kit (Hanna Instruments). The reactor effluent residual chlorine and the inlet free chlorine concentrations were measured before each biofilm sampling. The inlet chlorine concentration was measured from the concentrated chlorine container and corrected with the appropriate dilution factor. The chlorine demand was defined as the difference between the chlorine concentration at the inlet and the residual chlorine concentration at equilibrium in the outlet of the reactor. The reactor being perfectly mixed, the chlorine concentration in the effluent of the reactor was equal to the concentration in any point inside the reactor itself.

\subsection{Case 2: Urban heated water supply system}

\subsubsection{Experimental set-up}

Biofilms were developed in stainless steel annular reactors installed on a side stream of the return circuit in an urban heated water supply system (Figure 2). In order to study the $\mathrm{pH}$ effect on biofilm development, biofilm activity and corrosion, two alkaline $\mathrm{pH}$ conditions were tested, at $\mathrm{pH}$ of 8.2 and $\mathrm{pH}$ 9.2. Two reactors were operated for each $\mathrm{pH}$ condition.

Figure 2 Laboratory set-up to study biofilms in urban heat supply system

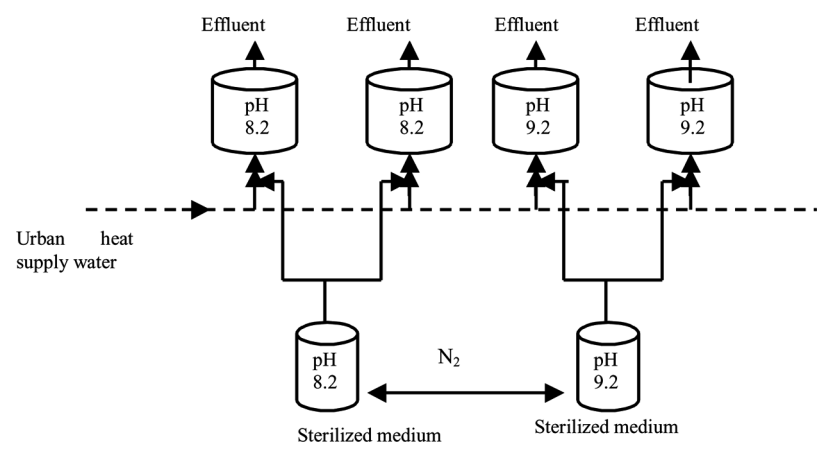

The annular reactors were composed of a stationary outer, and a rotating inner, cylinder ( $0.051 \mathrm{~m}$ inner radius and $0.056 \mathrm{~m}$ outer radius). The rotating drum allowed a constant shear force $\left(1 \mathrm{~N} . \mathrm{m}^{-2}\right)$ and a Reynolds number of 11842 . 
The total reactor volume was $1 \mathrm{~L}$ and the total internal surface area was $0.159 \mathrm{~m}^{2}$. The hydraulic residence time in the reactor was $1 \mathrm{~h}$ and the temperature was $30^{\circ} \mathrm{C}$. Test coupons of stainless steel (stainless steel 304 and stainless steel 316), mild steel and polycarbonate (control material) with a surface area of $13.8 \mathrm{~cm}^{2}$ (steel surfaces) and $57.64 \mathrm{~cm}^{2}$ (polycarbonate surface) were inserted in the annular reactor. The metallic coupons were degreased by ultrasonic cleaning in acetone and then dried in air (stainless steel coupons) or in nitrogen (mild steel) at room temperature before use. The reactors were operated with two influent streams: one with an urban heat supply water from the urban heated water supply system at a flow rate of approximately $0.96 \pm 0.04 \mathrm{Lh}^{-1}$ and the other with a sterilised aqueous medium containing sodium acetate, sodium sulphate and yeast extract that was pumped at a rate of $0.12 \pm 0.009 \mathrm{Lh}^{-1}$. The systems were completely closed and anaerobic conditions were kept by constantly bubbling nitrogen through the concentrated medium vessels.

No sulphide, sulphate or acetate were detected in the urban heated water system. After addition of the concentrated medium, final concentrations of $8.21 \pm 0.35 \mathrm{mgL}^{-1}$ sulphate, $6.22 \pm 0.35 \mathrm{mgL}^{-1}$ acetate and $5 \mathrm{mgL}^{-1}$ yeast extract were expected. The $\mathrm{pH}$ of the urban heated supply water was around $9.8 \pm 0.2$. Effluent samples were analysed for acetate and total sulphide $\left(\mathrm{H}_{2} \mathrm{~S}, \mathrm{HS}^{-}, \mathrm{S}^{2-}\right)$. Sulphide was colorimetrically quantified by the methylene blue method (Cline, 1969). Acetate concentrations in the influent and effluent streams were measured by ion chromatography suppressed conductivity. The substrate removal rate was calculated according to Lopes et al. (2006).

Steady state biofilms grown on mild steel, polycarbonate and stainless steel surfaces, SS 304 and SS316, were sampled after 64 days of operation. Biofilms were scraped off from the metal/polycarbonate surface using sterile cell scrapers into a solution of sterile filtered tap water and fixed with formaldehyde ( $2 \%$ final concentration, $v / v)$. The total number of cells was assessed in the biofilm samples by DAPI staining and epifluorescence microscopy enumeration. Acid-volatile sulphides (AVS: $\mathrm{H}_{2} \mathrm{~S}$ and $\mathrm{FeS}$ ) in steady-state biofilms were determined by the method originally developed by Fossing and Jorgensen (1989) and modified by Nielsen et al. (1993) for low sulphide concentrations. The time of extraction, acid volume and biofilm sample volume were optimised for sulphide extraction.

\subsubsection{Total number of cells in biofilm}

Fixed samples were washed with filtered distilled water, stained with DAPI (4'6-diamino-2-phenylindole) and filtered through blackened polycarbonate membranes. The total number of cells in biofilms was then enumerated at 1000x magnification using epifluorescence microscopy (filter set 01, Zeiss, Germany). Total cell numbers were based on counts from 15 to 20 randomly chosen fields.

\subsubsection{Fluorescence in-situ hybridisation}

Fluorescence in-situ hybridisation (FISH) was performed with $16 \mathrm{~S}$ and $23 \mathrm{~S}$ fluorescent rRNA-target nucleic acid probes on biofilm samples (Amann et al., 1995) according to Kjellerup et al. (2005). 
Biofilm samples were fixed in fresh $4 \%(\mathrm{w} / \mathrm{v})$ paraformaldehyde/PBS or $50 \%$ ethanol $(\mathrm{v} / \mathrm{v})$, washed three times with filtered distilled water, stained with DAPI as previously mentioned, immobilised on slides and hybridised.

Filter sets 01, 09 and 10 (Zeiss, Jena, Germany) were used with a 1000x magnification for microscopic examination. Cy3 labelled specific probes were used for enumeration. Total cell numbers in biofilms were determined on counts from 20 to 30 randomly chosen fields.

The following probes were used: EUB338-I+II+III or EUB338mix (Bacteria), NONEUB (nonsense probe), BET42a ( $\beta$-Proteobacteria), GAM42a ( $\gamma$-Proteobacteria), ALF968 ( $\alpha$-Proteobacteria), CF319a (Cytophaga-Flavobacteria), SRB385 ( $\delta$-Proteobacteria, Desulfovibrionacea), SRB385Db ( $\delta$-Proteobacteria, Desulfobacteriaceae) and ARCH915 (Domain Archae).

\subsection{Statistical analysis}

To test hypotheses about mean differences, comparisons were carried out at the $95 \%$ confidence level by the application of the independent samples $t$ test for two samples and by means of the one-way variance analysis (ANOVA) and Bonferroni test.

In order to determine the total number of biofilm cells per unit area of the annular reactor, the number of EUB338 mix target cells per unit of the reactor's surface area and the number of SRB per unit reactor's surface area for the urban heated water supply system, theorems concerning the distribution of sum, product and quotient of variables were applied (Duncan, 1974).

\section{Results and discussion}

\subsection{Case 1: Drinking water system}

Significant corrosion rapidly appeared at the surface of the mild steel coupons. After seven days, thick corrosion covered the majority of the surface coupon, leaving some apparently untouched spots. The corrosion presented the specific orange colour of ferric hydroxide, but dark corrosion layer(s), supposedly of magnetite and ferrous hydroxide, appeared when scraped. Under the corroded layers the metal surface presented extended and deep damage. The bacteriological analyses performed on the coupons before chlorination revealed that the biofilms scraped from the polymethylmetacrylate and mild steel coupon surfaces were composed of a mix of HPC bacteria. Pseudomonas spp., Alcaligenes spp., and Acinetobacter spp. were regularly isolated from the biofilms growing on both surfaces, as well as other Gram-negative and non-identified Gram-positive bacteria. All the identified bacteria are commonly found in fresh and potable water. It has to be noted that the API 20NE system failed to identify several bacteria, which is related to the difficulty in growing environmental bacteria. The characteristics of the biofilms grown on the mild steel and polymethylmetacrylate surfaces are presented in Table 1. 
Table 1 Characteristics of the biofilms grown on Mild Steel (MS) and polymethylmetacrylate (PMMA) coupons in the flow cell reactors

\begin{tabular}{lcccc}
\hline & $\begin{array}{c}\text { Cultivable bacteria } \\
\left.(\mathrm{CFU} \mathrm{cm})^{-2}\right)\end{array}$ & $\begin{array}{c}\text { Total bacteria } \\
\left(\text { cell cm }^{-2}\right)\end{array}$ & $\begin{array}{c}\text { Bacterial size } \\
(\text { length }, \mu \mathrm{m})\end{array}$ & $\begin{array}{c}\text { Viability } \\
(\%)\end{array}$ \\
\hline MS & $3.98 \times 10^{5} \pm 3.6 \times 10^{5}$ & $4.42 \times 10^{6} \pm 0.89 \times 10^{6}$ & $1.00 \pm 0.5$ & $8.2 \pm 5.9$ \\
PMMA & $3.66 \times 10^{5} \pm 2.42 \times 10^{5}$ & $2.95 \times 10^{6} \pm 1.78 \times 10^{6}$ & $1.37 \pm 0.65$ & $11.9 \pm 5.1$ \\
\hline
\end{tabular}

Average $\pm \mathrm{SD}$, Values are averaged from four replicate experiments $(\mathrm{SD}=$ standard deviation $)$.

The results showed no qualitative difference between the bacterial populations growing on steel and polymethylmetacrylate, indicating no specific selection of bacteria by the surface substrata after a week of growth. Kerr et al. (1999) found a greater bacterial diversity on cast iron than on plastic supports after 21 days of biofilm growth in tap water, but similar diversity after ten months. The bacterial density in biofilms grown on mild steel, as measured by the total number of bacteria per square centimetre, is higher than for biofilms on polymethylmetacrylate $(p<0.05)$. This may be due to the larger surface area developed by the corrosion or to a supposed attraction of bacteria for corrosion products. Little et al. (1999) demonstrated that Pseudomonas spp. were attracted to anodic regions on iron support and that this attraction was more influential than topography in determining the spatial distribution of the bacterial cells.

The results also showed that the association with corrosion products seemed to have an influence on the bacterial cell morphology and physiology (Table 1). The bacterial cells associated with the corroded surface (steel) were smaller (on average 37\% shorter) and less viable than those grown on polymethylmetacrylate (Table 1). In fact, the densities of cultivable bacteria were not significantly different for both types of biofilm $(p>0.05)$. Therefore, the viability of bacteria $\left(\mathrm{CFU} \mathrm{cm} /\right.$ total bacteria $\left.\mathrm{cm}^{-2}\right)$ was 1.4 times higher for those grown on polymethylmetacrylate coupons than for the ones developing on mild steel coupons. As both bacterial populations have the same origin, the difference in cell size is expected to be an indication of the relative physiological state of the micro-organisms and, consequently, of the environmental conditions that they are living in. Under stress, bacterial cells undergo physical and physiological changes such as alteration of the membrane composition and size reduction, among many others. This points to a survival strategy, allowing the bacteria to grow and multiply in stressful environments, such as drinking water (Morin et al., 1999).

Under the conditions of our experiments, the results obtained suggest that the bacteria growing on the corroded surface were more stressed than those developing on polymethylmetacrylate. The difference in viability of the two bacterial populations (Table 1) also showed that the bacteria associated with the polymethylmetacrylate were healthier than those developing on the corroded surface. This may be explained by the presence of these bacteria under the corrosion layers that would act like a diffusion barrier for oxygen, nutrients and bacterial metabolites. Several authors (LeChevallier et al., 1987; Beech et al., 1994) detected bacteria in the corrosion deposits and tubercles formed at the surface of pipe walls.

If the location of the biofilm within the corrosion layers is a stressing factor for the bacteria, it also surely plays a role in their physical protection. According to LeChevallier et al. (1987), such a protection plays an important role in the resistance of 
the biofilm to disinfection. Another crucial parameter in the response of biofilms to disinfection is the chlorine demand of the system in which they develop (Kiene et al., 1998). The residual chlorine concentration in the reactor effluents reached equilibrium after a maximum of $24 \mathrm{~h}$ of chlorination except in the case of the highest chlorination level in the 'corroded' reactor (residual chlorine concentration $0.9 \mathrm{mg} \mathrm{L}^{-1}$ ), where no plateau was attained. In Table 2 the influent and effluent chlorine concentrations are presented as well as the chlorine demands for the corroded and the control reactors.

Table 2 Influent and effluent chlorine concentrations and calculated chlorine demands of the corroded (MS) and the control reactors (PMMA)

\begin{tabular}{lcccc}
\hline Coupon & $C i\left(\mathrm{mg} \mathrm{L}^{-1}\right)$ & $C e\left(\mathrm{mg} \mathrm{L}^{-1}\right)$ & $r\left(\mathrm{mg} \mathrm{L}^{-1}\right)$ & Percentage \\
\hline MS & 0.53 & 0.11 & 0.42 & 79.25 \\
MS & 2.35 & 0.25 & 2.1 & 89.36 \\
MS & 2.93 & 0.40 & 2.53 & 86.35 \\
MS & 4.60 & 0.9 & 3.7 & 80.43 \\
PMMA & 0.57 & 0.24 & 0.33 & 57.89 \\
PMMA & 0.59 & 0.41 & 0.18 & 30.50 \\
PMMA & 0.64 & 0.42 & 0.22 & 34.37 \\
PMMA & 0.69 & 0.25 & 0.44 & 63.76 \\
PMMA & 0.80 & 0.37 & 0.43 & 53.75 \\
\hline
\end{tabular}

$\mathrm{Ci}$ : reactor influent free chlorine concentration.

$\mathrm{Ce}$ : reactor effluent free chlorine concentration.

$r=$ chlorine demand of the reactor.

$\%=(r \times 100 / C i)$.

The average chlorine demand was higher in the corroded reactor than in the control reactor, representing, on average, $84 \%$ of the inlet chlorine concentration against $48 \%$ for the control. Additionally, the chlorine demand of the corroded reactor was linearly dependent on the inlet chlorine concentration, whereas such a relation did not appear in the control reactor (data not shown). Figure 3 shows the bulk total iron concentration vs. time at different residual chlorine concentrations.

Figure 3 Total iron concentration in the corroded reactor effluent at different influent chlorine concentrations vs. time

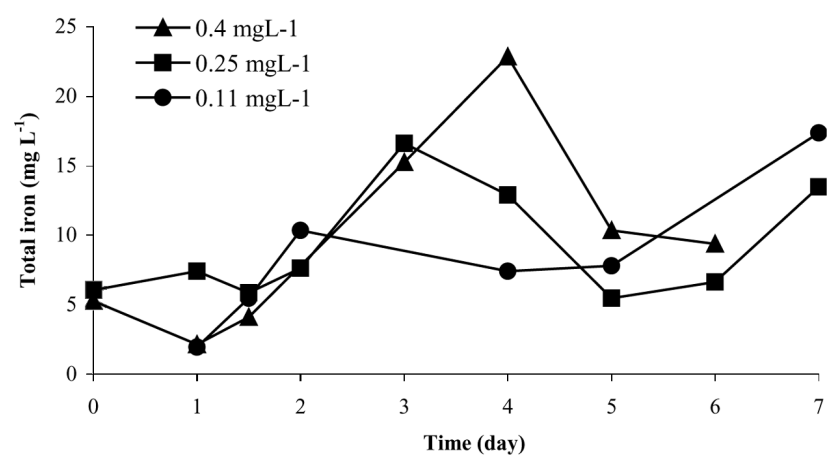


The maximum amount of iron in the bulk became higher when the residual chlorine in the corroded reactor increased. Furthermore, a positive linear relationship was measured between the chlorine demand and the bulk phase total iron $([\mathrm{Fe}]=5.58 r+7.03$; $R^{2}=0.92 ;[\mathrm{Fe}]-$ Total iron concentration, $\mathrm{mg} \mathrm{L}^{-1}$ and $r$ - Chlorine demand, $\mathrm{mg} \mathrm{L}^{-1}$ ). The data show that chlorine was not only consumed by the oxidation of the various components of the system but was also involved in iron dissolution through the oxidation of the surface of the coupons, therefore leading to a higher chlorine demand.

The results of the HPC and total bacteria counts in both biofilms are presented in Figure 4, respectively, for different residual chlorine concentrations.

Figure 4 (a) Biofilm total bacteria and (b) HPC counts vs. time for the corroded and the control reactors at different residual chlorine concentrations. (The results for the control reactor are the average of two replicate experiments. All the results were standardised to the average value at day 1 to help direct comparisons. Closed symbols: mild steel coupons; open symbols: polymethylmetacrylate coupons. Chlorine concentrations in $\mathrm{mg} \mathrm{L}^{-1}$ )

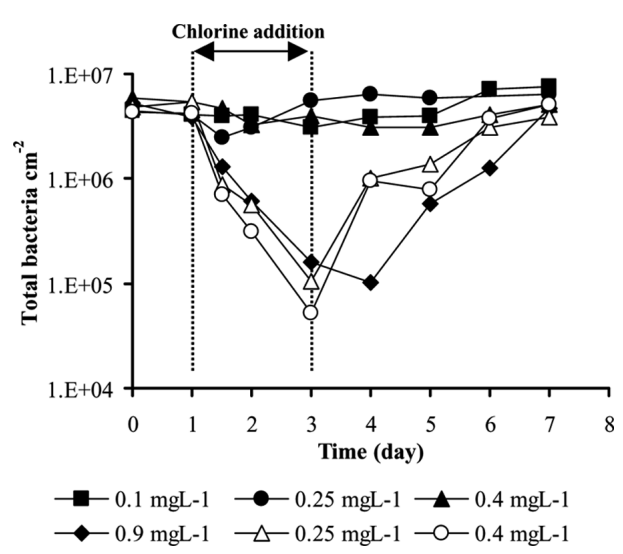

(a)

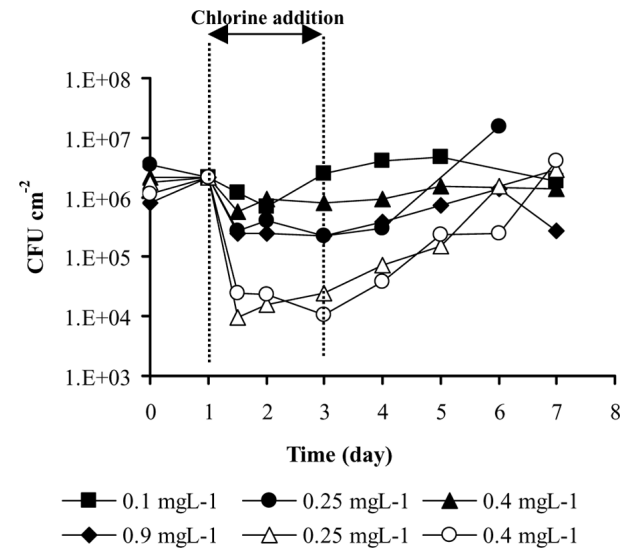

(b)

We can clearly notice the different impacts of sodium hypochlorite treatment on the cultivability of the biofilms developed on the metal coupons or on the inert coupons (Figure 4(b)) and on cell detachment (total bacteria counts results, Figure 4(a)). The effect of chlorination was more pronounced on the biofilms grown on polymethylmetacrylate than on the sessile bacteria developing on corroded mild steel.

Another interesting point, from Figure 4, is that, for each type of biofilm (corroded surface and control) the cultivability decay and detachment were independent of the residual chlorine concentration in the reactor. It seemed, therefore, that the disinfectant efficacy reached a maximum that was lower for the corroded system biofilms than for the control ones, confirming that the protective effect due to attachment to surfaces was enhanced in the case of the corroded coupons.

The average decay in cultivability for the biofilms grown on polymethylmetacrylate coupons was $99.5 \%( \pm 0.03)$ and the detachment of $98.3 \%( \pm 0.5)$. The corresponding values for the biofilms grown on the corroded surface were $80.2 \%( \pm 11.2)$ and $34.7 \%$ $( \pm 0.1)$ (cultivability and detachment decays were calculated as the difference between the HPC or total bacteria counts just before chlorination and the lowest HPC or total bacteria counts detected). These results suggest that the bacteria growing in association 
with corrosion were protected by sheltering and by high chlorine demand. Another (and non-exclusive) reason is that they have a better resistance to chlorination than the bacteria growing on polymethylmetacrylate because of their physiological characteristics promoting 'survival strategy', as explained earlier. Numerous works already demonstrated the difficulty to disinfect biofilms (LeChevallier et al., 1987; Neden et al., 1992; Mathieu et al., 1993; Morin and Camper, 1997). The efficacy of the disinfection decreases when the bacteria have the possibility to be physically protected on the surface through the production of extra cellular polymer and the presence of roughness, cavities, and when the chlorine demand of the environment is important. Percival et al. (1998) showed that the bacteria growing on stainless steel coupons in water mains were associated with crevices and embedded in EPS.

In the case of the corroded surface, the absence of efficiency of free chlorine for biofilm detachment (Figure 4(a)) is almost total but for the highest residual chlorine concentration $\left(0.9 \mathrm{mg} \mathrm{L}^{-1}\right)$ where $97 \%$ of the bacteria apparently detached. However, an artefact due to chlorination, more than an actual detachment, most probably caused this particular result. The results of CFU counts for the same replicate experiment did not show such an effect on bacterial viability (Figure 4(b)). Also, Saby et al. (1997) showed that the presence of free chlorine in solution decreased the staining of bacteria with DAPI and, therefore, increased the difficulty in seeing them. In our experiments, the bacteria associated with the corrosion layers on the metal coupons were already small before disinfection. It is, therefore, likely that a certain percentage of total bacteria were not enumerated, especially in the case of the higher residual chlorine concentration.

\subsection{Case 2: Urban heated water supply system}

The annular reactors were operated for 64 days. During this period, acetate and dissolved sulphide in the bulk liquid were regularly monitored in order to evaluate the developing biofilm activity. A steady-state was attained after approximately 20 days of operation. Evaluation of biofilm presence at steady-state was performed on test coupons of mild steel, stainless steel 316, stainless steel 304 and polycarbonate placed in the annular reactor. Microbial diversity of biofilms developed on steel and polycarbonate surfaces under the two $\mathrm{pH}$ conditions was assessed by fluorescence in-situ hybridisation.

Table 3 shows that an increase in $\mathrm{pH}$ is followed by lower acetate consumption rate $(p<0.05)$. Additionally, the total number of biofilm cells per unit area of the reactor is higher at a $\mathrm{pH}$ of 9.2 compared to a $\mathrm{pH}$ of 8.2 (Figure 5). These data suggest that the biofilms were more active when developed at the lower $\mathrm{pH}$ than at the higher one.

Table 3 Acetate removal and sulphide production rates at steady state for the two $\mathrm{pH}$ conditions

\begin{tabular}{lcc}
\hline Reactor $p H$ & Acetate $\left(\mu \mathrm{mol} \mathrm{h}^{-1} \mathrm{~m}^{-2}\right)$ & Sulphide $\left(\mu \mathrm{molS} \mathrm{h}^{-1} \mathrm{~m}^{-2}\right)$ \\
\hline 9.2 & $66.98 \pm 37.58$ & $29.76 \pm 5.80$ \\
8.2 & $117.74 \pm 30.25$ & $29.28 \pm 5.38$ \\
\hline
\end{tabular}

Average \pm SD (Standard Deviation).

A lower number of cells was detected in biofilms developed on stainless steel compared to mild steel and polycarbonate at a $\mathrm{pH}$ of $9.2(p<0.05)$. At a pH of 8.2, the highest 
cellular density was determined on mild steel as compared with all other surfaces $(p<0.05)$ (Table 4). Previous studies also reported a higher total bacteria number in biofilms developed on mild steel followed by stainless steel 316 and, finally, by copper in a heating system (Kjellerup et al., 2006).

Figure 5 Biofilm total cell number per unit of reactor's surface area

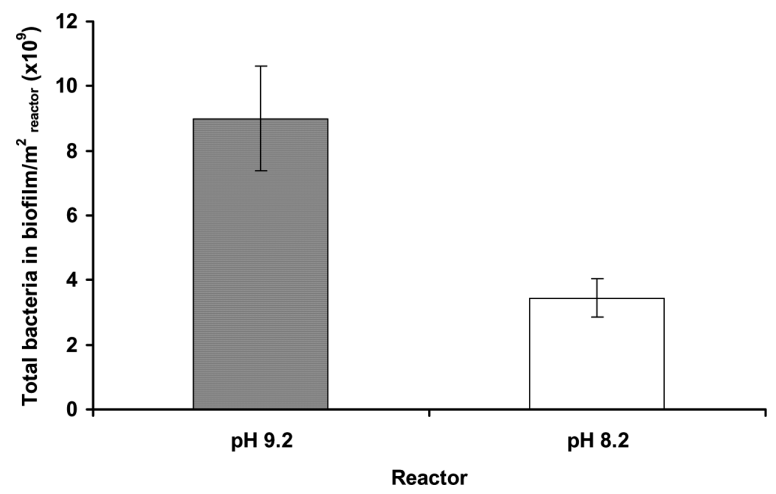

Table 4 Total cell number (DAPI) in biofilm per coupon unit area, at steady-state, on Mild Steel (MS), Polycarbonate (PC), stainless steel 316 and 304 (SS316, SS 304)

\begin{tabular}{|c|c|c|c|c|}
\hline Reactor $p H$ & $M S\left(\right.$ cells cm $\left.{ }^{-2}\right)$ & $P C\left(\right.$ cells cm $\left.\mathrm{cm}^{-2}\right)$ & SS304 (cells cm $\left.{ }^{-2}\right)$ & $S S 316\left(\right.$ cells cm $\left.{ }^{-2}\right)$ \\
\hline \multirow[t]{2}{*}{9.2} & $5.91 \times 10^{6}$ & $1.09 \times 10^{6}$ & $3.08 \times 10^{5}$ & $8.13 \times 10^{4}$ \\
\hline & $\pm 1.22 \times 10^{6}$ & $\pm 3.20 \times 10^{5}$ & $\pm 1.18 \times 10^{5}$ & $\pm 3.24 \times 10^{4}$ \\
\hline \multirow[t]{2}{*}{8.2} & $2.20 \times 10^{6}$ & $4.73 \times 10^{5}$ & $1.07 \times 10^{5}$ & $1.72 \times 10^{5}$ \\
\hline & $\pm 4.43 \times 10^{5}$ & $\pm 1.59 \times 10^{5}$ & $\pm 2.75 \times 10^{4}$ & $\pm 4.16 \times 10^{4}$ \\
\hline
\end{tabular}

Average $\pm \mathrm{SD}(\mathrm{SD}=$ standard deviation $)$.

Figures 6 and 7 and Table 5 present the results obtained by FISH screening on biofilms developed on Mild Steel (MS) and Polycarbonate (PC) for the two pH conditions.

Table 5 Screening of bacterial diversity of biofilms on Mild Steel (MS) and Polycarbonate (PC) developed at $\mathrm{pH} 8.2$ and 9.2 (\% of DAPI counts)

\begin{tabular}{lcccc}
\hline Reactor & GAM42a & ALF968 & SRB & CF319a \\
\hline MS pH8 & $2.18 \pm 0.92$ & $0.12 \pm 0.03$ & $0.73 \pm 0.40$ & $1.80 \pm 0.96$ \\
PC pH8 & $1.45 \pm 0.27$ & $*$ & $1.27 \pm 0.58$ & - \\
MS pH9 & $*$ & ND & $*$ & $1.54 \pm 1.27$ \\
PC pH9 & $1.46 \pm 0.28$ & $1.23 \pm 0.47$ & $0.61 \pm 0.47$ & - \\
\hline
\end{tabular}

${ }^{\mathrm{a}} \mathrm{SBR}$ is the total enumeration of SRB385 and SRB385Db.

ND -Not detected.

*Less than $1 \%$.

- Not tested. 
Figure 6 EUB338mix/DAPI ratio of biofilms on Mild Steel (MS) and Polycarbonate (PC) for the two $\mathrm{pH}$ conditions. Vertical bars represent standard deviation from at least two coupons

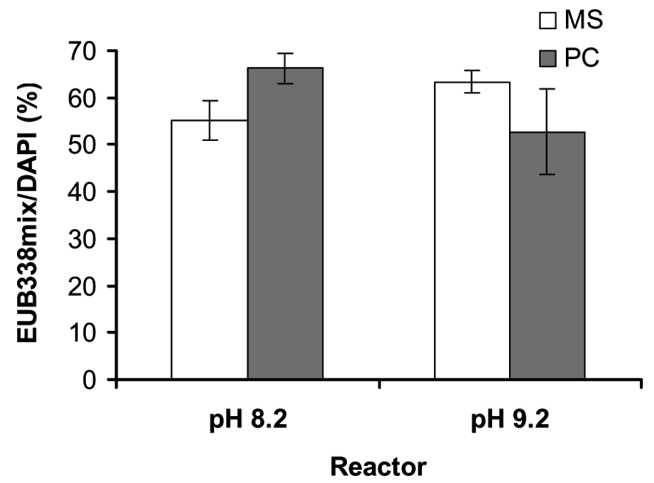

Figure 7 BET42a/DAPI ratio of biofilms on Mild Steel (MS) and Polycarbonate (PC) for the two $\mathrm{pH}$ conditions. Vertical bars represent standard deviation from at least two coupons

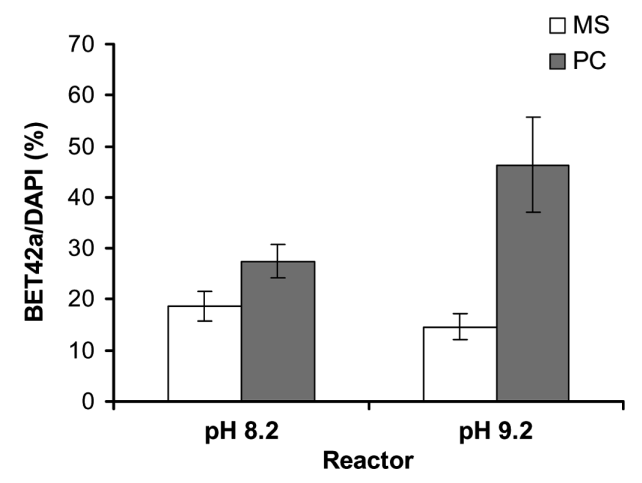

The FISH screening showed that the proportion of total bacteria stained with DAPI that could hybridise with the general probe for Bacteria (ratio between EUB338mix and DAPI) was higher than $50 \%$ for biofilms developed on mild steel and polycarbonate at a $\mathrm{pH}$ of 8.2 and a $\mathrm{pH}$ of 9.2 (Figure 6). Since the detection of FISH positive cells is dependent on the cellular rRNA content and taking into account the fact that metabolic activity was detected in both biofilm reactors (consumption of acetate and production of sulphide), these results proved that a very high fraction of bacteria in these biofilms were metabolically active. The remaining fraction of micro-organisms were either dead or too small to contain enough ribosomes and, consequently, enough target sites for the probes, or were impermeable to the tested probe (Weiss et al., 1996).

Additionally, a higher EUB338mix/DAPI ratio on biofilms developed on a polycarbonate surface, compared with mild steel for the reactor operating at a $\mathrm{pH}$ of 8.2 , was detected $(p<0.05)$. The EUB338mix/DAPI ratios for stainless steel 304 and 316 were $66.5 \%$ and $40.3 \%$ for a $\mathrm{pH}$ of 8.2 , and $47.3 \%$ and $51.2 \%$ at a $\mathrm{pH}$ of 9.2 , respectively. Furthermore, the EUB338mix target cells per unit of reactor's surface area were higher at a $\mathrm{pH}$ of 9.2 compared with a $\mathrm{pH}$ of $8.2\left(6.88 \times 10^{9} \pm 1.30 \times 10^{9}\right.$ and $2.40 \times 10^{9} \pm 0.45 \times 10^{9}$ EUB338mix-cells $\mathrm{m}^{-2}$, for $\mathrm{pH} 9.2$ and 8.2 , respectively), suggesting a higher bacterial activity at lower $\mathrm{pH}$, as previously suggested. 
$\beta$-Proteobacteria was the predominant group of bacteria in all biofilms (Figure 7). BET42a accounts for more than $30 \%$ of EUB338 determined in all biofilm samples. The prevalence of members of the $\beta$-Proteobacteria has been reported in other aquatic habitats, such as activated sludge, oligotrophic aquatic systems and heating systems and might be a common feature of most aquatic environments (Kalmbach et al., 1997). FISH screening applied to biofilms developed in urban heating systems showed EUB338/DAPI ratios varying from $68 \%$ to $31 \%$ and demonstrated that $\beta$-Proteobacteria (BET42a) was the most dominant group, with a BET42a/DAPI ratio around 23-29\% (Kjellerup et al., 2002).

Table 5 presents the results obtained when applying group-specific probes other than EUB338mix and Bet42a to the biofilm samples.

Results from Table 5 show that $\alpha, \gamma$ and $\delta$-Proteobacteria and CytophagaFlavobacteria only constituted a low percentage of these biofilms population. The ARCH915/DAPI ratio on biofilm samples was less than 1\%, suggesting that Archae were not present in these biofilms (data not shown).

As expected, sulphate reducing bacteria were detected in these samples, by monitoring sulphide production in the reactors (Table 3). They were mostly attached to corrosion products or inorganic material. The high amount of corrosion products, particularly in biofilms formed on mild steel, emitted intense fluorescence when Cy3-labelled probes were applied for cell enumeration. Therefore, it was difficult to distinguish between this autofluorescence and the one due to hybridisation of Cy3-probes SRB385 and SRB385Db, as previously reported (Okabe et al., 1999). Consequently, the SRB/DAPI ratio may be underestimated. The presence of bacteria from $\delta$-subclass of Proteobacteria (probe SRB385) was also detected in other district heating systems (Kjellerup et al., 2002).

Biofilms developed on mild steel coupons were analysed for Acid Volatile Sulphide (AVS) in order to evaluate the formation of corrosion products. A higher content of corrosion compounds was measured in biofilms developed at a $\mathrm{pH}$ of 8.2 $\left(10.5 \pm 2.60 \mathrm{nmolS} \mathrm{cm}{ }^{-2}\right.$ and $0.7 \pm 0.13 \mathrm{nmolS} \mathrm{cm}{ }^{-2}$ for $\mathrm{pH} 8.2$ and $\mathrm{pH} 9.2$, respectively). As previously referred, bacteria from the biofilm developed at a $\mathrm{pH}$ of 8.2 may be more active, leading to higher amounts of AVS compounds within these biofilms. It should be noticed that sulphide production (Table 3 ) refers to bulk sulphide concentrations and does not include the sulphide that precipitated/reacted with the metal. When considering the total sulphide from the AVS compounds, the sulphide production rate was increased to $30.62 \mu \mathrm{molS} \mathrm{m} \mathrm{m}^{-2} \mathrm{~h}^{-1}$ and $42.4 \mu \mathrm{molS} \mathrm{m} \mathrm{m}^{-2}$ for $\mathrm{pH} 9.2$ and $\mathrm{pH} 8.2$, respectively. Furthermore, it should be pointed out that a similar number of SRBs per unit reactor's surface area were determined in both biofilms $\left(4.1 \times 10^{7}\right.$ and $3.4 \times 10^{7} \mathrm{SRB} \mathrm{m}{ }^{-2}$ at $\mathrm{pH} 9.2$ and $\mathrm{pH} 8.2$, respectively) suggesting a higher sulphate reducing activity in biofilms developed at $\mathrm{pH} 8.2$, which is in good agreement with previous data. The use of alkaline conditions as a means of controlling SRB activity in industrial systems has been suggested in literature. From the present study, it is possible to conclude that SRB were active in alkaline conditions, although they may be less active at $\mathrm{pH}$ higher than 8.2.

Specific sulphide production rates of $17.8 \times 10^{-12}$ and $29.8 \times 10^{-12} \mathrm{molS} \mathrm{SRB}^{-1}$ day $^{-1}$ at $\mathrm{pH} 9.2$ and $\mathrm{pH} 8.2$ were determined in the present study, respectively. Santegoeds et al.

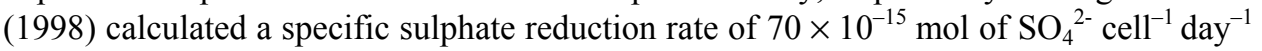
and estimated a relative percentage of SRB bacteria of less than $1 \%$. These authors proposed that either the SRB were extremely active or the FISH technique was 
underestimating the number of SRB. Accordingly, it appears that the number of SRB was also underestimated in our study, as previously suggested.

Corrosion was observed on mild steel coupons for both $\mathrm{pH}$ conditions. Moreover, it appeared that general corrosion, characterised by a strongly attached black layer, was spread all over the steel surface. The mild steel coupons from the reactor working at a $\mathrm{pH}$ of 9.2 showed a thin and homogeneous layer of magnetite with few irregularities (weak attacks). The homogenous layer of sulphide behaved as a protective film, passivating the metal surface and preventing further corrosion. Thus, corrosion appears to depend primarily on the physical-chemical nature of the corrosion products rather than on SRB activity. Accelerated corrosion rates have been observed when iron, corroded by SRB, was exposed to intermittent aerobic-anaerobic environments. (Lee et al., 1995). In the present study, the reactors were always working under anaerobic conditions; therefore, lower corrosion rates were expected.

\section{Conclusions}

The results of this work emphasise the need for an integrated analysis of the biofilm phenomenon on metal surfaces, showing that a series of combined parameters affect biofouling development and the associated corrosion mechanisms. Such parameters include surface properties, $\mathrm{pH}$ and chlorine content in water, as well as bacterial diversity.

Biofilms formed on a corroded surface (mild steel surface) in a drinking water system were highly resistant to chlorination suggesting that the corrosion layer acts as a protective film and reduces the efficacy of the biocide. However, the bacteria of this 'corroded' biofilm are not as healthy as those developed on the inert surface, probably because of the diffusion barrier introduced by the corrosion layers over the biofilm. Their physiological state may, however, induce a higher resistance to environmental stresses.

The data also showed lower number of cells on stainless steel as compared to mild steel and polycarbonate in an urban heated water supply system. As regards the microbial population diversity in biofilms, the $\beta$-Proteobacteria were found to be the predominant bacteria. A very significant fraction of bacteria were metabolically active in biofilms developed on steel and polycarbonate surfaces. Furthermore, biofilm activity seemed to be higher near neutral $\mathrm{pH}$ values. Although sulphate reducing bacteria were detected in the urban heating system, probably more active at lower $\mathrm{pH}$, very little corrosion was detected in those operating conditions, reinforcing the fact that corrosion appeared to depend on the physical-chemical nature of the corrosion products rather than on SRB activity.

\section{Acknowledgements}

The authors acknowledge the financial support of Programme Praxis XXI (Grant Praxis $\mathrm{XXI} / \mathrm{BD} / 13462 / 97$ ) and of the Danish Government (Cirius - Danish Centre for International Cooperation and Mobility in Education and Training). 
Filipa Lopes acknowledges the support of Professor P.H. Nielsen of the Department of Biotechnology, Chemistry and Environmental Engineering, Section of Environmental Engineering from Aalborg University in Denmark, B.V. Kjellerup and Merete for their help in the urban heated water supply system research work.

\section{References}

Amann, R.I., Ludwig, W. and Schleifer, K.H. (1995) 'Phylogenetic identification and in situ detection of individual microbial cells without cultivation', Microbiological Review, Vol. 59, pp.143-169.

Clesceri, L.S. (Ed.) (1989) Standard Methods for the Examination of Water and Wastewaster, 17th ed., American Public Health Association, Washington, DC, USA.

Beech, I.B. and Sunner, J. (2004) 'Biocorrosion: towards understanding interactions between biofilms and metals', Current Opinion in Biotechnology, Vol. 15, pp.181-186.

Beech, I.B., Edyvean, R.G.J., Cheung, C.W.S. and Turner, A. (1994) 'Bacteria and corrosion in potable water mains', Proceedings of 3rd International EFC Workshop, Microbial corrosion, European Federation of Corrosion, Portugal, pp.328-337.

Block, J-C., Haudidier, K., Paquin, J.L., Miazga, J. and Levi, Y. (1993) 'Biofilm accumulation in drinking water distribution systems', Biofouling, Vol. 6, pp.333-343.

Bott, T.R. (1995) Biological Growth on Heat Exchanger Surfaces in Fouling of Heat Exchangers, Elsevier, Amsterdam, Chapt. 12, pp.223-267.

Cline, J.D. (1969) 'Spectrophotometric determinations of hydrogen sulphide in natural waters', Limnol. Oceanogr., Vol. 14, pp.454-458.

Duncan, A.J. (1974) Distribution of Sums and Differences in Quality Control and Industrial Statistics, in Irwin, R.D. (Ed.), Illinois, pp.102-106.

Dunkelberger, G.W. and Carey, E. (1991) 'Bacterial inoculation of water distribution systems', Proceedings of the Am. Wat. Works Assoc. Water Quality Technology Conference, Orlando, pp.811-821.

Fossing, H. and Jorgensen, B.B. (1989) 'Measurement of bacterial sulphate reduction in sediments: evaluation of a single-step chromium reduction method', Biogeochem., Vol. 8, pp.205-222.

Geesey, G., Beech, I., Bremer, P., Webster, B.J. and Wells, D.B. (2000) 'Biocorrosion', in Bryers, J. (Ed.): Biofilms II Process Analysis and Applications, New York, pp.281-325.

Gibson, G.R. (1990) 'Physiology and ecology of the sulphate-reducing bacteria', J Appl Bacteriol, Vol. 69, pp.769-797.

Goeres, D.M., Nielsen, P.H., Smidt, H.D. and FrØlund, B. (1998) 'The effect of alkaline pH conditions on a sulphate reducing consortium from a danish district heating plant', Biofouling, Vol. 12, No. 4, pp.273-286.

Hamilton, W.A. (1995) 'Microbial biofilms', in Lappin-Scott, H.M. and Costerton, J.W. (Eds.): Biofilms and Microbially Influenced Corrosion in Microbial Biofilms, University Press, Cambridge.

Hamilton, W.A. (1999) 'Microbially influenced corrosion in the context of metal microbe interactions', Proceedings of the 4th International EFC Workshop, Microbial Corrosion, European Federation of Corrosion publications, Lisboa, Portugal, pp.1-17.

Kalmbach, S., Manz, W. and Szewzyk, U. (1997) 'Dynamics of biofilm formation in drinking water: phylogenetic affiliation and metabolic potential of single cells assessed by formazan reduction and in situ hybridization', FEMS Microbiology Ecology, Vol. 22, pp.265-279.

Kerr, C.J., Osborn, K.S., Robson, G.D. and Handley, P.S. (1999) 'The relationship between pipe material and biofilm formation in a laboratory model system', J. Appl. Microbiol. Symp. Suppl., Vol. 85, pp.29S-38S. 
Kiene, L., Lu, W. and Levi, Y. (1998) 'Relative importance of the phenomena responsible for chlorine decay in drinking water distribution systems', Wat. Sci. Tech., Vol. 38, No. 6, pp.219-227.

Kjellerup, B.V., Gudmonsson, G., Sowers, K. and Nielsen, P.H. (2006) 'Evaluation of analytical methods for determining the distribution of biofilm and active bacteria in a commercial heating system', Biofouling, Vol. 22, No. 3, pp.145-151.

Kjellerup, B.V., Olesen, B.H., Nielsen, J.L., FrØlund, B., Ødum, S. and Nielsen, P.H. (2002) 'Monitoring and characterisation of bacteria in corroding district heating systems using fluorescence in situ hybridisation (FISH) and microautoradiography (MAR)', Proceedings of the International Specialised Conference on Biofilm Monitoring, Porto, Portugal, 17-20 March.

Kjellerup, B.V., Thomsen, T.R., Nielsen, J.L., Olesen, B.H., FrØlund, B. and Nielsen, P.H. (2005) 'Microbial diversity in biofilms from corroding heating systems', Biofouling, Vol. 21, No. 1, pp.19-29.

Laurent, P., Servais, P. and Randon, G. (1993) 'Bacterial development in distribution networks - study and modelling', Wat. Supply, Vol. 11, Nos.3-4, pp.387-398.

LeChevallier, M.W., Babcock, T.M. and Lee, R.G. (1987) 'Examination and characterization of standard plate count bacteria in chlorinated and raw water supplies', Appl. Environ. Microbiol., Vol. 53, No. 12, pp.2714-2724.

Lee, W., Lewandowski, Z., Nielsen, P.H. and Hamilton, W.A. (1995) 'Role of sulfate-reducing bacteria in corrosion of mild steel: a review', Biofouling, Vol. 8, pp.165-194.

Little, B.J., Ray, R.I., Wagner, P.A., Jones-Meehan, J., Lee, C.C. and Mansfeld, F. (1999) 'Spatial relationships between marine bacteria and localized corrosion on polymer coated steel', Biofouling, Vol. 13, No. 4, pp.301-321.

Little, B.J., Wagner, P.A., Characklis, W.G. and Lee, W. (1990) 'Microbial corrosion', in Characklis, W.G. and Marshall, K.C. (Eds.): Biofilms, Wiley-interscience Publication, Vol. 16, New York, pp.635-670.

Lopes, F.A., Morin, P., Oliveira, R. and Melo, L.F. (2006) 'Interaction of Desulfovibrio desulfuricans biofilms with stainless steel surface and its impact on bacterial metabolism', Journal of Applied Microbiology, Vol. 101, pp.1087-1095.

Mathieu, L., Block, J.C., Dutang, M., Maillard, J. and Reasoner, D.J. (1993) 'Control of biofilm accumulation in drinking water distribution systems', Water Supply, Vol. 11, Nos. 3-4, pp.365-376.

Melo, L.F. (2003) 'Biofilm formation and its role in fixed film processes', in Nigel Horan (Eds.): The Handbook of Water and Wastewater Microbiology, Academic Press, Duncan Mara, London, pp.337-349.

Morin, P. and Camper, A.K. (1997) 'Attachment and fate of carbon fines in simulated drinking water distribution system biofilms', Wat. Res., Vol. 31, No. 3, pp.399-410.

Morin, P., Camper, A.K., Jones, W., Gatel, D. and Goldman, J.C. (1996) 'Colonization and disinfection of biofilms hosting coliform-colonized carbon fines', Appl. Environ. Microbiol., Vol. 62, Vol. 12, pp.4428-4432.

Morin, P., Gauthier, V., Saby, S. and Block, J-C. (1999) 'Bacterial resistance to chlorine through attachment to particles and pipe surfaces in drinking water distribution systems in Biofilms in the Aquatic Environment', in Keevil, C.W., Godfree, A.F., Holt, D.M. and Dow C.S. (Eds.): Royal Society of Chemistry, pp.171-190.

Neden, D.G., Jones, R.J., Smith, J.R., Kirmeyer, G.J. and Foust, G.W. (1992) 'Comparing chlorination and chloramination for controlling bacterial regrowth', J. Am. Wat. Works Assoc., Vol. 84, No.7, pp.80-88.

Nielsen, P.H., Lee, W., Lewandowski, M.M. and Characklis, W. (1993) 'Corrosion of mild steel in an alternating oxic and anoxic biofilm system', Biofouling, Vol. 7, pp.267-284. 
Okabe, S., Itoh, T., Satoh, H. and Watanabe, Y. (1999) 'Analysis of spatial distributions of sulfate-reducing bacteria and their activity in aerobic wastewater biofilms', Appl. Environ. Microbiol., Vol. 65, No. 11, pp.5107-5116.

Patel, T.D. and Bott, T.R. (1991) 'Oxygen diffusion through a developing biofilm of Pseudomonas fluorescens', J. Chem. Tech. Biotechnol., Vol. 52, pp.187-199.

Percival, S.L., Knapp, J.S., Edyvean, R. and Wales, D.S. (1998) 'Biofilm development on stainless steel in mains water', Wat. Res., Vol. 32, No. 1, pp.243-253.

Pereira, M.O., Morin, P., Vieira, M.J. and Melo, L.F. (2002) 'A versatile reactor for continuous monitoring of biofilm properties in laboratory and industrial conditions', Letters Applied Microbiology, Vol. 34, pp.22-26.

Saby, S., Sibille, I., Mathieu, L., Paquin, J-L. and Block, J-C. (1997) 'Influence of water chlorination on the counting of bacteria with DAPI', Appl. Environ. Microbiol., Vol. 63, No. 4, pp.1564-1569.

Santegoeds, C.M., Ferdelman, T., Muyzer, G. and De Beer, D. (1998) 'Structural and functional dynamics of sulfate-reducing populations in bacterial biofilms', Applied and Environmental Microbiology., Vol. 64, No. 10, pp.3731-3739.

Videla, H.A. (2002) 'Prevention and control of biocorrosion', International Biodeterioration and Biodegradation, Vol. 49, pp.259-270.

Videla, H.A. and Herrera, L.K. (2005) 'Microbiologically influenced corrosion: looking to the future', International Microbiology, Vol. 8, pp.169-180.

Weiss, P., Schweitzer, B., Amann, R. and Simon, M. (1996) 'Identification in situ dynamics of bacteria on limnetic organic aggregates (lake snow)', Applied and Environmental Microbiology, Vol. 62, No. 6, pp.1998-2005.

Xu, K.D., Stewart, P.S., Xia, F., Huang, C-T. and McFeters, G.A. (1998) 'Spatial physiological heterogeneity in Pseudomonas aeruginosa is determined by oxygen availability', Appl. Environ. Microbiol., Vol. 64, No. 10, pp.4035-4039. 